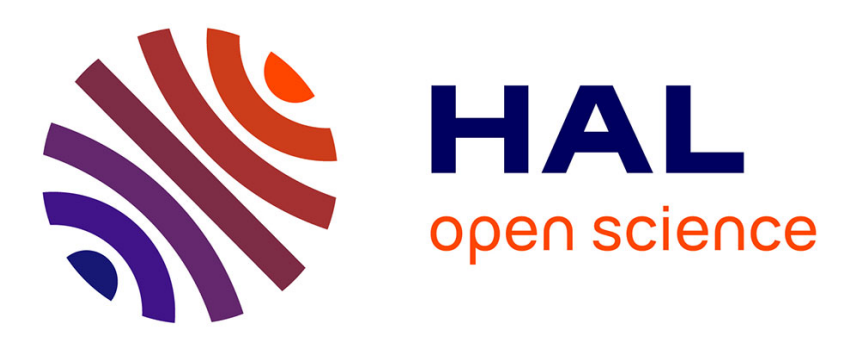

\title{
Trees in the landscape: orchard trees in a seventeenth century French dictionary
}

Geoffrey Williams

\section{To cite this version:}

Geoffrey Williams. Trees in the landscape: orchard trees in a seventeenth century French dictionary. Lexicographica. International Annual for Lexicography, 2021, 37, 10.1515/lex-2021-0011 . hal-03587670

\author{
HAL Id: hal-03587670 \\ https://hal.science/hal-03587670
}

Submitted on 24 Feb 2022

HAL is a multi-disciplinary open access archive for the deposit and dissemination of scientific research documents, whether they are published or not. The documents may come from teaching and research institutions in France or abroad, or from public or private research centers.
L'archive ouverte pluridisciplinaire HAL, est destinée au dépôt et à la diffusion de documents scientifiques de niveau recherche, publiés ou non, émanant des établissements d'enseignement et de recherche français ou étrangers, des laboratoires publics ou privés. 


\title{
Trees in the landscape: orchard trees in a seventeenth century French dictionary
}

\author{
Geoffrey Williams, Université de Bretagne Sud, 4 rue Jean Zay, 56321 Lorient, France
}

williams@licorn-research.fr

\begin{abstract}
:
The seventeenth century was a time of change in both agriculture and architecture as both nobility and newly rich bourgeois sought to embellish country residences with gardens and orchards. Not only were new plants arriving from overseas, but gardening was being revolutionised by the likes of Le Nôtre, de la Quintinie and the lesser known Fatio. This was reflected in the Dictionnaire universel de Antoine Furetière, the first genuinely encyclopaedic dictionary. This paper starts by introducing the LandLex initiative, pan-European synchronic and diachronic collaborative analyses of simple words concerning the landscape in historical dictionaries. We then look at a selected number of orchard trees and their fruit in two editions of the Dictionnaire universel: the first edition of 1690 and that revised by Basnage de Beauval in 1701. To an extent, Furetière applied a model for classifying trees and fruit that can be extracted by analysis. Some entries went into excessive detail a those of pear, a highly fashionable fruit at the time. One major difference between the two is Basnage's move from a single author approach to the use of field experts in certain areas, amongst which botany. Much was simply carried over, but when Dr. Régis, Basnage's expert in medicine and natural history, deemed an entry of scientific interest it was given a rewrite with new background texts being cited, thereby widening our vision of developing seventeenth century science.
\end{abstract}

Keywords: LandLex, Historical dictionaries, Dictionnaire universel, Botany, Gardening

1. Introduction

Trees form an essential part of our landscape and as such have a place in the dictionary, both in terms of the word itself, and the different types of tree that are found in any one language. Even the word 'tree' itself opens lexicographical vistas. Johnson (Johnson 1785) describes them as "a large vegetable, rising with one woody item to a considerable height". Succinct, and possibly confusing. In his Dictionnaire Universel (henceforth DU) (Furetière 1690) says of trees that they are « Le premier \& le plus grand des vegetaux, qui pousse beaucoup de branches \& de feuilles, qui jette beaucoup de bois » (the first and the tallest of plants, which grows many branches and leaves, which produces much wood), whilst in the 1701 edition of the same, Basnage, (Furetière, s. d.) adds « qui n'a qu'un seul tronc » (which has a single trunk). This is sufficient to get a gist of what is a tree, but the important thing is that both Johnson and the DU go on to give long encyclopaedic entries to better understand these kings of the plant kingdom. What we find immediately is the continuum between trees and shrubs, but also that trees are often found in groups; forests, woods, coppices, orchards. It is the latter that concern us here.

The seventeenth century was a time of change for the landed aristocracy and the rising bourgeois. It was a period when houses were no longer defensive and becoming symbols of success and comfort. They needed to produce food for the house, but also to have a formal garden for show. It was the period of Le Notre, and a period of a more scientific approach to gardening with a strong interest in orchard trees and their management. It is also the beginning of modern French cuisine with the publication of works by La Varennes, chef to the Marquis of Uzelles. Insofar as the Dictionnaire Universel is an encyclopaedic dictionary 
with an emphasis of terms, it is an excellent starting point for an exploration of seventeenth century orchards and fruit growing.

However developed they may be, $17^{\text {th }}$ and $18^{\text {th }}$ century encyclopaedic dictionaries were highly personal undertakings and can tell us a lot about the author and the world in which they were created. This is very much the case with the Dictionnaire Universel and much can be learned from comparing the 1690 edition of Furetière and the enlarged and revised edition of 1701 under the editorship of Henri Basnage de Beauval. In this paper, we shall mostly concentrate on the latter edition and one particular aspect: orchard trees in the landscape. However, the paper will start with an introduction to the LandLex project, an investigation into landscape and its description in legacy dictionaries, before introducing the Dictionnaire Universel and the BasNum project which is building a fully XML-TEI compliant open access version of the 1701 edition, with working copies of both the 1690 and later editions. We shall then look specifically at the description of fruit trees and raise the question as to who actually wrote these entries, Henri Basnage or his specialist on medical and scientific questions, a certain Dr Régis of Amsterdam mentioned in the preface to the 1701 edition.

\section{Working Context}

\subsection{LandLex}

LandLex is an informal gathering of specialists in lexicography and lexicology that came about due to a meeting of minds during the European Network for e-Lexicography (ENeL) COST action. The group has in common an interest in word histories, as opposed to formal etymology, as they are illustrated in legacy dictionaries. This entails not only looking at the evolution of senses in dictionaries over time within a single language, but above all considering the interaction and cross fertilisation between languages across the European lexicographical tradition.

The European lexicographical tradition is rich and reflects the wealth and variety of European languages and cultures. This would make for a very broad brief if we had not limited our studies to words pertaining to the landscape, and even then not the entirety of landscapeoriented words but a small selection on which detailed analysis could be carried out with the ultimate aim of improving contemporary dictionaries whilst improving access to data in legacy work. People relate strongly with their environment so that a dictionary will reflect not only central meanings of words, but also how those are interpreted in different language and cultural settings. This is often done through encyclopaedic information and the use of citations and examples thereby giving access to connotational aspects of meaning that are highly language-dependant.

In building our models, LandLex participants concentrated on a small number of words concerning plants, landscape features and colours. The words chosen for deep analysis 'hill', 'daisy' and 'red' - are the subject of a recent collective work that gives a pan-European perspective on landscape language in lexicographical descriptions (Villalva et Williams 2019). Current work aims to look at another ubiquitous aspect of the landscape - trees. The coppice - woods - forest continuum is a fascinating one, but here we concentrate solely on trees cultivated for the fruit they produce, orchard trees.

What is grown in an orchard depends very much on climate, so each study of trees and fruits will differ from one region to another and from a period in time to another depending on when they were introduced into Europe. This study takes a French perspective and looks 
mostly at prototypical orchard trees and their fruits in Northern France in late seventeenth century dictionaries.

\subsection{Seventeenth century France}

The seventeenth century was a time of change across all of Europe, but notably in France. It was a time of transition from the renaissance to the contemporary world in many ways from architecture to language. If the Republic of letters and the enlightenment typifies the eighteenth century, then both were born in the seventeenth century. It was a time of academies in the world of science - Accademia dei Lincei (1603), and Sciences (1666), Royal Society (1660), Preußische Akademie der Künste (1694/1696).

In terms of lexicography, and hence the Lex of LandLex, this is the beginning of the age of the Academic dictionary (Considine 2014), notably with foundation of the Accademia della Crusca (1583) and its dictionary, the Vocabolario degli Accademici della Crusca (Accademia della Crusca 1612) and the founding of the Académie Française (1635) and the publication of its dictionary (Académie Française 1694). The seventeenth century was remarkably rich in dictionaries, particularly in France, starting with the dictionary of Nicod (Nicot et de Ranconnet 1606) and witnessing the birth of the first encyclopaedic dictionary, the Dictionnaire Universel of Furetière in 1690, with the edition studied here from 1701. As for 'land' in LandLex, the seventeenth century saw major changes in agriculture and gardening. This is the century of André Le Nôtre, gardener to the Roi Soleil, Louis XIV, and his most magnificent creation, the gardens of Versailles. The formal 'jardins à la française' also found their place in the numerous 'maison de plaisance', country homes, built for the lesser nobility and rising bourgeoisie. It was not simply a question of formal pleasure gardens, fruit and vegetables, and hence the planting of orchards, were equally important as gardening became more scientific. The influx of new plants from foreign travel also gave impetus to gardening and the science of botany which was increasingly concerned with systematic classification.

All of this comes together in the 1701 edition of the Dictionnaire Universel.

\subsection{Basnage and BasNum}

The Basnage project is a long-term endeavour to explore the work of a forgotten French lexicographer, Henri Basnage de Beauval. Whilst Bernard Quémada (Quémada 1967) deals at length with Furetière, the creator of the DU, he almost totally overlooks Basnage. This is not so surprising as Basnage never put claim to the dictionary, but he is the man who totally revised it and made it into the rich encyclopaedic dictionary that influenced many others, both directly and indirectly, and opened the way to Chambers' Cyclopaedia (Chambers 1728) the Diderot \& Alembert Encyclopédie (Diderot et Le Rond d'Alembert 1751).

The DU was the brainchild of Antoine Furetière, a bourgeois clergyman, abbot at a distance of the Abbey de Chalivoi, and member of the Académie Française. Frustrated with the interminable discussions and slowness of the Académie in producing their dictionary, he set out to produce his own. He obtained publication rights, a 'privilège', on the basis that it would cover the terms of arts, crafts and sciences, and therefore not be a rival to the Academy which had exclusive rights to publish any dictionary in France at that time (Rey 2006). In fact, his plan for a universal dictionary stepped well over the mark and led to fierce exchanges with the Academy, the revocation of his 'privilège', and his exclusion from the Academy. Furetière died in 1688 a combative, but bitter man. However, Furetière had had the foresight to arrange 
for publication of his masterwork in the Netherlands with the Dutch publisher Leers. The Dictionnaire Universel was published in 1690 to great acclaim, including at the French court.

The publication of the DU in the Netherlands did stimulate activity in the Academy which finally published its dictionary (Académie Française 1694), accompanied by a dictionary of terms in crafts and sciences (Corneille 1694), which was largely based on that of Richelet (Richelet 1680). The publication of two rival dictionaries in turn incited Leers to seek a new edition of the DU, and for this he turned to a French protestant refugee who had already made his mark as editor of the journal Histoire des ouvrages des savants, Henri Basnage de Beauval ${ }^{1}$.

Henri Basnage came from a recently ennobled, but old and established, protestant family based in Rouen, Normandy. His father had been President of the Parliament of Normandy and was a highly respected figure. Henri was himself a lawyer. The family had extensive lands in Normandy. Henri's elder brother Jacques, a protestant pastor, moved to the Netherlands in 1685, following the Revocation of the Edit of Nantes, which had banned Protestantism within the Kingdom. Henri followed and established himself in Rotterdam. Asked by Leers in 1695 to take on a new edition of the DU, Henri Basnage accepted and produced his new enlarged edition in 1701. Insofar as Furetière's dictionary had been published posthumously, it had not had sufficient proofreading and needed heavy revision with the result of Basnage's work being tripled in volume. More importantly, Basnage never saw himself as possessing universal knowledge and called upon specialists for more scientific entries. The preface to the second edition (Furetière 1701) notes that for medical and natural history related issues, he had called upon a Doctor Régis of Amsterdam, of whom almost nothing is known. Basnage does not tell us who wrote which entry and so one of the tasks in the BasNum project is to try and differentiate the authorial styles of different contributors.

The 1701 DU drew upon a variety of contemporary dictionaries, including the Richelet (Richelet 1680) and that of the Académie Française, neither of which Furetière acknowledged. It went on to three other editions - 1702, 1708 and 1725/27 - and was republished in 1704 as the Dictionnaire de Trévoux, a total copy by the Jesuits of Trévoux who never acknowledged the source. This means that some used the DU directly in their own endeavours, such as Bluteau for Portuguese, whilst other, as Chambers and his Cyclopaedia (1728) drew on the Trévoux, amongst others. The best way to analyse such dictionaries is to have access to fully digitised XML-TEI versions and that is what the French nationally funded $\left(\mathrm{ANR}^{2}\right)$ BasNum project is doing.

BasNum is using advanced technology to further its aims and will make that technology, along with the dictionaries we digitise, fully available. After an initial transcription of the text using Transkribus ${ }^{3}$, two main series of tools are applied. The first is GROBID Dictionaries (Khemakhem, Foppiano, et Romary 2017) and the second a series of tools currently under development using artificial intelligence to seek named entities, primarily persons named, places and organisations. Named entities are particularly important in the project as we are endeavouring to trace all the authors and works cited. The tool will find the names, and to an extent handle the abbreviations used in the dictionary, but the task of finding out who is who is a major human undertaking. When possible, author names are linked to the International Standard Name Identifier (ISNI ${ }^{4}$ ) so as to ensure disambiguation and give biographical

\footnotetext{
${ }^{1}$ See the recent thesis by Sara Graveleau (Graveleau 2018) for a discussion of the life of Basnage.

${ }^{2} \mathrm{https}$ //anr.fr/Projet-ANR-18-CE38-0003

${ }^{3}$ https://transkribus.eu/Transkribus/

${ }^{4} \mathrm{http}: / /$ www.isni.org
} 
information. GROBID Dictionaries applies the principle of Ordered Hierarchies of Content Objects $(\mathrm{OHCO})$ in order to seek out structure and apply appropriate TEI tags. Dictionaries are highly structured documents and therefore well adapted to such computational routines. However, legacy dictionaries are a source of numerous difficulties, starting with the quality of the image and the use of both spellings and characters, such as the long 's' and ligatured 'ct' that characterise early dictionaries.

As in modern dictionaries, the entry is signalled by a headword, for which there may be several spellings as the DU often takes a known spelling, such as 'ESPICE' (spice) and follows it with the spelling the lexicographer wishes to impose, such as ' $E P I C E$ ', the current spelling. Surprising situations can arise when, for example, as late as the 1727 edition of the DU, the spelling ORENGE is still given as the main entry whilst admitting that the Académie Française, generally the reference for correct usage, prefers ORANGE. Grammatical information, when it exists, follows the headword, but this is not always easy to interpret as one of the unfulfilled tasks of the Académie had been to supply a grammar so that whilst both grammatical and phonetic considerations are present, both may be discussed before moving on to the senses and definitions.

Whilst the main entry structures are easily found, the microstructure can be distinctly idiosyncratic, making it difficult to identify sub-senses and related entries. Etymologies do not follow modern practice and are generally embedded word histories, which adds another complication. This can make automatic mark-up difficult, but not impossible as GROBID Dictionaries uses machine learning techniques so that the system will learn from sample pages that have been manually corrected. It is however a lengthy process and every dictionary, and every edition of that dictionary is unique.

\section{Fruit trees in the seventeenth century landscape}

In 1690 'Paysage' (landscape) was still a recent word in what is now its more general sense of referring to the countryside. Furetière reminds us that the word was essentially used by artists to depict a format and a certain type of content. The artists landscape was an essentially idealised one and, even now, its collocational resonance ${ }^{5}$ gives meanings that are diffused with nostalgia as the word inevitably speaks of an idealized scene from foreground to horizon with a frame. Contents are expected to reveal beauty, and this is clear in the definition provided by Furetière and Basnage. Both the 1690 and 1701 editions list features of the prototypical late seventeenth century landscape. Listing such features allows the use of the notion of collocational networks (Williams 1998) in order to explore a corpus, or in this case a dictionary, thematically by following textual links (Fig. 1).

Figure 1. Collocational network from 'paisage' to orchard.

Amongst the features of the landscape, we find 'maison de plaisance', (country houses). It was a fashion in the seventeenth century for the bourgeois, in addition to the nobility, to have a place in the country at which to relax with friends and acquaintances. This meant a rise in building in the classical style approved by Basnage (Williams 2020) and the formal pleasure

\footnotetext{
${ }^{5}$ See (Williams 2019) for a discussion of collocational resonance in the context of landscape.
} 
gardens that had come into fashion with the work of André Le Nôtre. The style of garden to be expected is described in the 1701 DU:

JARDIN s.m. Terre cultivée qu'on menage au derriere d'une maison pour lui donner de l'air, pour se promener, \& pour lui servir d'ornement. Les jardins sont composez de parterres pour les fleurs, de potagers, de vergers, de bois de haute fûtaye, \& d'allées, selon leur diverse étenduë. ${ }^{6}$

This definition shows the importance of a well-structured garden and links to the essential notion of an orchard. Equally significant is the definition for the act of gardening:

JARDINAGE. subst. masc. L'art de cultiver les jardins. [...] Le jardinage a été mis depuis peu de temps en un haut point de perfection par le Sr. le Nostre. La Quintinie est encore allé plus loin, \& nous a donné une ample instruction sur le jardinage. Mr. Fatio a donné, depuis quelques mois (1699) au public un livre sur le jardinage où il enseigne les moyens d'employer utilement les reflexions du soleil. [... $]^{7}$

The first part of the definition is copied verbatim from the 1690 edition, what I have underlined is the addition by Basnage. This entry is useful as it illustrates two important features of the dictionary: the working method of Basnage and the recourse to the latest scientific knowledge. It is clear that Basnage did not have the time to rewrite all the definitions as Leers needed the work out quickly. Thus, when he agreed with Furetière's text, it seems clear that he would use a cut and paste principle in which he would paste in his additions after the definition of his predecessor. This is clearly the case in the above entries as what is underlined is what new elements have been brought to this edition. Throughout this text, underlining will be used to show what is in common between entries. The second factor is his knowledge and insistence on up-to-date sources. Basnage was not only the editor of a journal that reviewed the most recent publications in many fields of arts and sciences, but he was himself a member of both the Academy of Berlin and the Royal Society. In addition, he maintained a wide ranging correspondence with the European elite, including Leibniz, who was himself contemplating a dictionary.

In the case of gardens and orchards, the encyclopaedic information is interesting in the light of a member of the landed gentry in exile, who was still concerned with his forfeited estates. Jean Baptiste de la Quintinie (1626-1688) was a lawyer by training, but had abandoned the law to become an agronomist and gardener. It was he who had created the vegetable gardens for the King at Versailles, and his book 'Instruction pour les jardins fruitiers et potagers'(Instructions for fruit and vegetable gardens) published in 1690 was very influential. The second work is even more interesting as Nicolas Fatio de Duillier (1664-1753) was not a gardener but an astronomer and member of the Royal Society, and it was the Royal Society that published his work on 'Fruit-walls improved, by inclining them to the horizon, or, $A$ way to build walls for fruit-trees whereby they may receive more sun shine, and heat, than ordinary'. A citizen of Geneva, he was born in Basel, but had lived mostly in The Hague and finally England. It is possible that he could actually have met Basnage during his stay in the

\footnotetext{
${ }^{6}$ Garden noun, masculine. Cultivated ground that is laid out behind a house so as to give it space, to walk and to serve as an ornament. The gardens are composed of flower beds, vegetable garden, orchards, woods of high trees, and alleys, in accordance with the space.

${ }^{7}$ Gardening, noun, masculine. The art of cultivating gardens. [...] Gardening has been brought in recent times to a high level of perfection by M. Le Nôtre. La Quintinie has gone even further and has provided ample instruction on gardening. M. Fatio has given in the last months a book on gardening where is taught the means to usefully use reflections from the sun. [...]
} 
low countries. His work had great significance as his studies on the sun and its movements formed the basis for wall building and the placing of greenhouses as the growing of more exotic fruits became possible in Northern climes.

Whilst the entries for gardens and gardening were probably written by Basnage, entries from botany came within the brief of Dr Régis. This aspect will be looked at later.

The DU has a strong interest in gardening as is reflected by the fifty terms listed for gardening and the seventy listed as terms used by gardeners. This list includes many terms related to the maintenance of orchards, including terms of grafting. The interest in gardens and garden products, and notably what is produced in an orchard, requires being put into the perspective of a developing interest in fine cooking in the seventeenth century, very much a preoccupation of Furetière, and the interests of a member of the landed nobility exiled in the Netherlands but retaining an interest in the family estates ${ }^{8}$. This interest in orchards and orchard products reflects the personal interests of the authors so that encyclopaedic information is mixed with highly detailed entries for garden management and very lengthy descriptions of some orchards fruits as 'pomme' (apple - one and a half pages) and 'poire' (pear - two pages).

The trees and their fruit that we deal with here are essentially those that are found in northern climes: apple, pear, plum and quince, but also softer fruits as apricots and peaches. Although oranges and olives can be grown in Southern France, they are far from a typical feature further north. Both will however be discussed as it is one in which Furetière took a particular interest.

Entries do not follow a clear pattern, but looking at entries it is possible to build some form of prototypical dictionary entry pattern. The fruits discussed are thus the orchard crops: cognaissier (quince), pescher (peach), poirier (pear), pommier (apple) and prunier (plum), plus the more exotic 'orenge' (orange) and olive. It should be noted that the current spelling of the peach tree is pêcher and the fruit pêche.

\subsection{Apple trees}

In Northern climes, apples and pears are staple fruits, both for eating and drink, with cider, written as 'sidre' in the entries, and perry, both being more frequent in many northern regions than wine. Jacques Basnage, brother of Henri, had managed to retain some hold on his estates and was in correspondence with his friend François Asselin (1673-1751), chevalier de Frenelle, about the management of the land. Letters concern the crops of peaches, pears, plums, apples and apricots (Graveleau 2018, 106). He was also concerned by the cider which he had exported to his home in the Netherlands (Graveleau 2018, 121). Fruit and fruit trees were therefore of great importance. Nevertheless, the definitions of both Furetière and Basnage are the same for apple and pear trees, simply copied over without modification.

POMMIER. s. m. Arbre qui porte les pommes. Pommier nain; pommier en plein vent; pommier sauvage ; pommier enté sur franc, ou sur sauvageon. Le pommier jette plusieurs branches qui s'étendent en long \& en large. Ses feuilles sont oblongues ou presque rondes, les unes pointues, les autres obtuses, legerement crenelées aux bords. Ses fleurs sont à cinq feuilles disposées en rose, de couleur blanche, ou d'un blanche é de purpurin, d'une odeur agreable. Quand elles sont passées, il leur succede des fruits charnus, presque

\footnotetext{
${ }^{8}$ See (Graveleau 2018) for a discussion of the management of the estates of the exiled Basnage family.
} 
ronds, qu'on appelle pommes. Ses racines sont longues, ligneuses, presque à fleur de terre. En Latin malus sativa. On éleve des pommiers sur franc \& sur paradis ; \& pour faire des buissons, le paradis est le plus propre, demeurant toûjours nain. Il y a une espece de sauvageon de pommiers, nommée doucins, qui pousse beaucoup de jets au pied, qui a beaucoup plus de seve que le pommier de paradis, qui est une espece de doucins qui jette du pied.

The definition starts with a standard formula - 'Arbre qui porte les [name of fruit]' that will be used for all fruit trees. He then gives a typology of trees - dwarf, standard, wild, grafted (enté). The branch structure of the tree is given as well as the shape of the leaves. The flowers only get a mention for their agreeable smell. He mentions the fruit, the root system and the botanical Latin malus sativa. The need for Latin classification is interesting as classification did not yet know the stable Linnaean system now used for Malus domestica. Botany was of great interest to Dr. Régis, but he obviously did not consider it necessary to rewrite this entry.

If we turn to pear trees, the entry is even shorter:

POIRIER. s. m. Arbre qui porte des poires. Le bois de poirier reçoit un beau poli, $\&$ on en fait des buffets qu'on noircit comme de l'ébene. Il y a de deux sortes de poiriers. L'un est cultivé, \& l'autre sauvage. Le poirier sauvage est plus petit que le cultivé. Ses rameaux sont garnis d'épines dures \& piquantes.

The introductory formula is the same. The difference here is that he mentions the wood of the tree because it has a particular use in cabinet making. Otherwise, he mentions two sorts, cultivated and wild, and the branches. Fruit trees obviously did not inspire lexicographical effort on behalf of Basnage.

\subsection{Rewritten entries : quince and plum trees}

Whilst apple and pear trees did not inspire a rewrite, 'coignaissier' (quince) clearly did as can be seen by comparing the two texts below. This is not simply a copy and paste with added information, someone thought that more care was needed and the answer probably lies in the origins of the fruit in the East, which makes it more of a botanical specimen. The first text is that of Furetière, the second that of the DU 1701. The underlined text is what is common between the two.

\section{$\underline{\text { DU } 1690}$}

Arbre qui porte les coignasses. Les Jardiniers font deux sortes d'entes, les unes sur frac, \& les autres sur coignassier. Le coignassier ne devient gueres grand, à cause de la pesanteur de son fruit, qui fait pancher ses branches vers la terre. Il est quasi semblable au pommier, mais ses feuilles sont plus estroites, lissées, charneuses, plus dures \& plus blanches à l'envers. Les pommes de coin furent premierement apportées en Italie de Cydon ville de Candie: d'où vient que les Grecs et les Latins les ont appellées mala cydonia. Les meilleurs especes viennent de Nevers \& d'Orléans. Le meilleur cotignac est de coignassier.

\section{$\underline{\text { DU } 1701}$}

COIGNASSIER, ou COIGNIER. s. m. Arbre qui porte les coins, \& qui ne devient jamais fort grand à cause de la pesanteur de son fruit qui fait pancher ses branches 
vers la terre. Son bois est tortu, pâle \& blanc par dedans, assez ferme \& égal. Ses feuilles sont semblables à celles du pommier, fort cotonnées sur le dos, lisses \& vertes de l'autre côté : elles ne sont point decoupées sur les bords. Ses fleurs ressemblent à celle des roses sauvages : elles sont composées de cinq feuilles presque rondes $\&$ de couleur de chair. Sa semence est renfermée dans son fruit : elle rend l'eau dans laquelle on la fait tremper, épaisse \& mucilagineuse. Son fruit est appelle coin, il en sera parlé en son lieu. Quelques Jardiniers disent que le coignier est le mâle, \& le coignassier la femelle. La Quintinie pretend qu'il n'y nulle difference. On a donné au cognassier le nom de cydonia. Ce mot vient de Cydon ville de Candie, d'où ce fruit fut porté en Grece. On l'appelle aussi malus cotonea. Les meilleures especes viennent de Nevers \& d'Orleans.

The introductory formula is stable and some of the information is carried over, but the rest is much more detailed as to the nature of the fruit and its origins. We also have mention of La Quintinie again with a discussion of whether there is a difference between male and female plants. Naming is also interesting as we have the introduction of a new name, 'coignier', based on a new name for the fruit 'coin'. Current spelling is 'cognassier' for the tree and 'coing' for the fruit. The botanical Latin also changes from 'mala cydonia' to 'malus cotonea'. The plant is now classified as Cydonia oblonga and is the only one in the Cydonia family. One other detail to which we shall return is the end of Furetière's text where he mentions the best 'cotignac'. This is a very sweet fruit paste made with quince that is a specialty of Orleans. Once again, Furetière's interest in gourmet food comes to the fore.

Plum trees also get a rewrite, moving from a very short text in 1690 to a far more elaborated one in 1701.

DU 1690

Arbre qui porte des prunes. On dit proverbialement, Il est sot comme un prunier, sans qu'on voye le fondement de ce proverbe.

DU 1701

PRUNIER. s. m. Arbre dont il y a deux especes generales, un cultivé \& l'autre sauvage. Le prunier cultivé est d'une hauteur \& d'une grosseur mediocre. Ses feuilles sont un peu longues, crenelées tout autour. Ses fleurs sont blanches, composées de cinq feuilles disposées en rose. Ses fruits qu'on nomme prunes, sont charnus, couverts d'une peau mince ; il y en a beaucoup d'especes qui different par leur grosseur, par leur figure, par leur couleur, par leur goût. En Latin prunus sativa. C. Bauh. La decoction des feuilles du prunier est bonne pour arrêter les fluxions qui tombent sur la luette $\&$ sur les gencives, si on s'en lave la bouche. Les prunes douces ramolissent \& lachent le ventre. On dit proverbialement, il est sot comme un prunier, sans qu'on voye le fondement de ce proverbe. A l'égard du prunier sauvage, voyez Prunellier.

Furetière was obviously not interested in plum trees as he only says it carries fruit and then gives this obscure proverb comparing a fool to a plum tree. The writer of the 1701 entry clearly thought it deserved more, giving it the full description we have found for apple, pear and quince trees. He then adds the botanical Latin and medical information 
for a mouthwash from the leaves and gives the fruit as a laxative. The source for the botanical Latin is given as being Gaspard Bauhin (1560-1624), also known as Caspard, which explains the ' $\mathrm{C}$ ' in the abbreviation. Bauhin, who came from a French huguenot family that had settled in Switzerland, was an early botanist, amongst the first to propose a classification of plants. He was also an anatomist, which would point to his works being owned by someone with medical training.

Rather than continuing to compare tree by tree, we can now give an overall picture of how the entries for trees are constructed.

\subsection{Classifying data for trees}

It is clear that although the fuller entries for apple and pear were carried over from Furetière, the other entries benefited from much greater care and something approaching a systematic description. The following list of features can be found:

- spelling and grammatical information

- introductory formula - Arbre qui porte les [name of fruit]

- description of varieties

- description of wood if wood has value

- description of leaves

- description of flowers

- description of fruit shape

- botanical Latin

- medical usage

- botanical name

Using this template, the following table shows the degree to which the pattern is respected.

\begin{tabular}{|c|c|c|c|c|c|c|c|c|c|c|}
\hline Tree & Fruit & Variety & Wood & Height & Leaves & Flowers & Fruit sha & Latin & Medical & Grafted \\
\hline Abricoti & $x$ & & & & $x$ & $x$ & $x$ & $x$ & & \\
\hline Coignass & $5 X$ & $x$ & $\mathrm{X}$ & $X$ & & & & & & $\mathrm{X}$ \\
\hline Pescher & $x$ & & & & $x$ & $x$ & & $x$ & $x$ & $x$ \\
\hline Poirier & $x$ & $x$ & $x$ & & & & & & & \\
\hline Pommie & $x$ & $x$ & & & $x$ & $x$ & & $x$ & & \\
\hline Prunier & $\mathrm{x}$ & $x$ & $\mathrm{X}$ & $x$ & $\mathrm{X}$ & $\mathrm{x}$ & $x$ & $X$ & $x$ & \\
\hline
\end{tabular}

Only the naming formula is the same everywhere, with the exception of the plum tree. Elsewhere there is a great deal more variation, perhaps reflected in the perceived interest of the tree. However, what is noteworthy is the inclusion of more botanical Latin as well as medical information. To go deeper, we shall now turn to the actual fruit.

\section{Fruit and their description}

The trees and their fruit get a somewhat different treatment as although the former required some additional botanical information, it is the fruit that are consumed and should therefore have a potential medical interest. However, we actually find less intervention from Dr Régis and more a concentration on the gustative value as fruits were of great importance in the 
seventeenth and eighteenth century aristiocratic diet, which explains why some entries, copied verebatim, are extremely long and detailed as to varieties available in different seasons. This emphasis on variety and season will become clear in the comparative table.

\subsection{Apples}

POMME. s. f. C'est le plus connu de tous les fruits, qui est rond \& à pepin, qui vient en été \& en automne, qui est bon à manger \& à faire du sidre. Il y a d'ordinaire dans les pommes quinze grosses fibres, dont dix sont distribuées dans toute l'étendue de la pulpe, \& enfin s'accrochent \& se joignent ensemble vers le nombril ou œil de la pomme ; \& les cinq autres passent en ligne droite du pedicule ou de la queue jusqu'à cet œil, ou elles se mêlent \& s'unissent avec les dix premieres. Celles-ci sont principalement destinées à nourrir les pepins ou la graine.

The main entry for 'pomme' in both editions is exactly the same with a description of the fruit, round and with pips, being a summer and autumn fruit and good for both eating and making cider, the current French being 'cidre'. After this discussion of the fruit and its particularities follows a long paragraph listing the varieties and their qualities. The only change is the last line where a precision is added, "on appelle pommes jumelles, des pommes qui viennent attachées l'une à l'autre" (one calls twin apples, apples that come attached one to the other), a simple observation from someone used to picking apples, presumably Basnage himself. Both editions continue with information from the botanist Italian Pietro Andrea Matthioli (1501-1577), in French Matthiole, on the effects of rootstock on the taste of the fruit. Both tell us these uses for apples, including apple pies.

Now the editions differ in that the 1701 DU has an added sense for 'Pomme d'Adam' (Adam's apple). This is not in the bodily sense, but refers to a particular type of fruit that resembles and tastes like a lemon. A detailed description is given and includes the story that some believe it to be the fruit that Adam ate in the Garden of Eden. Reference is made to Caspard Bauhin, pointing to this sense having been written by someone with botanical knowledge. The actual fruit is mentioned in various eighteenth century medical dictionaries, but appears to be a variety of lemon. The importance in this study is we may well have an entry produced by two hands, Basnage adding comments to the main entry and Dr Régis bringing in his botanical information.

The entry now includes another sense from Furetière 1690 that starts with "Les Medecins Botaniques décrivent une plante qu'ils appellent pommes d'amour" (the botanical medical doctors describe a plant they call pommes d'amour). This gets a total rewrite under the heading of 'Pomme Dorée', or 'Pomme d'Amour'. The entry is detailed and differs greatly from that of Furetière. It calls upon a specialist reference in the shape of Mr. Tournefort. This is Joseph Pitton de Tournefort (1656-1708), doctor and botanist, holder of the chair in Botany of the Collège Royal and author of 'Éléments de botanique ou méthode pour connaître les plantes' printed at the Imprimerie royale of Paris in 1694. Thus again, this is probably not the standard readings of Basnage but specialist input.

After a short mention of 'Pomme Épineuse' or 'Pomme de Perou', which is simply a crossreference to 'Stramonium', a flowering plant and not a tree, comes the sense for 'Pomme de merveille', which again benefits from a total rewrite with reference to Tournefort and discussion of its medical properties. 
The rest of this lengthy entry is copied verbatim from the 1690 edition.

\subsection{Pears}

If we now turn to pears, we find an even more lengthy entry spread over three pages of the 1701 edition. The main entry is exactly the same between the two editions:

POIRE. s. f. Fruit à pepins d'été \& d'hiver, de figure oblongue, \& plus menu vers la queuë que vers la tête. Il y en a une infinité de sortes. Voici la liste des principales dont les livres font mention, \& qui sont recherchées par les curieux, distribuées selon les temps qu'elles meurissent, ou qu'on les mange. Premierement, [...]

This is a brief definition following the model for apple. What follows is a series of paragraphs listing the varieties and the qualities by season throughout the year from July to May. The only difference with the 1690 edition is the addition of a related entry for 'Poires Secretes' stated as being a 'terme d'Éperonnier', a spur maker. This means that neither Basnage nor Dr Régis found anything particular to add.

\subsection{Quince and plum}

We now move to two fruits for which the tree entry had either had additions or a rewrite.

Starting with quince we find a complete copy over from Furetière 1690 right down to the definition of the fruit being buried in a larger entry for 'coin' in the sense of being an angle. The fruit, with its two spellings the second of which is now in current use, is given along with a description of the fruit, its uses, notably in case of illness, its use in proverbs and the botanical Latin.

Coin, ou Coing, est aussi une espece de fruit à pepin, gros, cottonneux \& pierreux, qui est de la figure d'une poire, \& qui jette une odeur très-forte quand il est enfermé. Le coin est astringent \& fort propre pour fortifier l'estomac. On s'en sert dans le vomissement, dans le cours de ventre, \& dans le hoquet. On fait cuire des coins sous la cendre. Le cotignac se fait de coins. On dit d'un malade de la jaunisse, qu'il est jaune comme un coin. En Latin cydonium, cotoneum malum. L'arbre qui le porte s'appelle coignassier ou coignier.

That quince should have not required changes would follow from the supposition that the entry for the fruit tree was from Basnage, who simply added information and a reference to the gardening work of La Quintinie. The situation is different with plum, the entry for the tree having been largely rewritten.

PRUNE. s. f. Fruit d'été qui est à noyau avec une pulpe ou chair couverte d'une peau fleurie. Il y a des prunes de plusieurs sortes, d'imperiales, de damas, de brignoles, de mirabelle, de dattes. Il y en a de rouges, de jaunes, de blanches, $\&$ de violettes ; des prunes-pommes, prunes-noix, \&c. En Latin prunum. Matthiole dit qu'il y a des prunes vertes, rouges, de couleur d'yvoire, jaunes \& purpurines ; de grosses, petites, moyennes ; de rondes, de longuettes, enovale ; de dures \& de molles ; de douces, d'aigres, de vineuses \& de pisseuses. C'est un fruit qui nuit à l'estomach, \& lâche le ventre.

The main entry does not differ between the two editions. The fruit is described as having pips, thereby completing the classification into kernel and pips. As with other fruit, different types are mentioned. Furetière is particularly concerned with prunes being a cause of flatulence. The definition is followed by a section on proverbial usage, which is the same except for the 
addition of one line, "si je suis affligé, ce n'est pas pour des prunes" (the literal translation is 'if I am afflicted, it is not for the plums', but the phrase is a play on words as the formula 'ce n'est pas pour les prunes' actually means 'it is not for nothing'). This is referenced to Molière and in fact comes from the short play 'Sganarelle ou le Cocu imaginaire'. Basnage is simply placing a quotation from one of his favourite playwrights'.

What follows is a lengthy description of varieties and their qualities that is copied over from the 1690 DU. In order words, Furetière was as ever concerned with the gustative qualities of fruit, Basnage just wanted to add a reference and Dr Régis saw nothing for a botanist and medical practitioner to add.

\subsection{Peaches and peach trees}

Peaches are a particular case as the first problem is to locate the sense for 'pesche' and 'pescher'. The problem arises not so much from the spelling, current spellings are respectively 'pêche' and 'pêcher', but from Furetière and Basnage's treatment of related entries and homographs.

In the 1690 edition, the tree 'pescher' is given as a related entry for the fruit 'pesche', whereas the 1701 DU treats 'pesche' as an entry in its own right. The actual text does not differ between the two editions. For the fruit however, Basnage groups a series of words under the entry 'pesche' starting with "l'Action par laquelle on prendre $d u$ poisson; l'art de prendre du poisson" (action by which one catches fish, the art of catching fish). Indeed, the word forms for fishing and peaches are homographs, but so is the word for the tree and the verb for 'to fish', but in this case we have two separate entries. The fruit arises after a discussion of fishing and the laws relating to fishing with the opening line of 'peach, is also a large fruit':

Pesche, est aussi un gros fruit à noyau qui vient sur la fin de l'été, des plus delicieux qui se mangent. La premiere \& la plus hâtive est l'avantpêche musquée, qui est blanche \& petite, douce \& sucrée. La pêche de Troye est une avantpéche musquée rouge qui est plus grosse ; \& une autre qu'on nomme la double de Troye, est plus ronde.

The text is exactly the same between the two editions, starting with explaining that it is a fruit with a kernel and that it is delicious and comes into season at the end of summer. There is then a discussion of one column in length describing different varieties of peach. The entry ends with the comment that "Il y a aussi plusieurs autres espèces de pêches [...] qui ont de la peine à mourir en ces pays-ici" (there are also other species of peach $[\ldots]$ which have difficulty to ripen in this country). In other words, both Furetière and Basnage are content with peaches as a pleasant fruit and nothing more. The last line does serve to emphasise the importance of the work of Fatio mentioned earlier on growing fragile fruits in northern climes.

\subsection{Classifying data for fruit}

\footnotetext{
${ }^{9}$ See Ioana Galleron (Galleron 2020)for a discussion of the works of Molière in the 1701 Dictionnaire universel.
} 
As for trees, it is now possible to sum up the information to be found in the 1701 entries as can be seen in the following table:

\begin{tabular}{|c|c|c|c|c|c|c|c|c|c|c|}
\hline Fruit & Fruit à $\mathrm{p}$ & Fruit à n & Family & Taste & Smell & Shape & Colour & & s Season & Medical \\
\hline Abricot & & & pêche/pl & $x$ & & $x$ & $x$ & $x$ & $x$ & \\
\hline Coing & $x$ & & & $x$ & $x$ & $x$ & & & & $x$ \\
\hline Pesche & & $x$ & & & & $x$ & & $x$ & $x$ & \\
\hline Poire & $x$ & & & & & $x$ & & $x$ & $x$ & \\
\hline Pomme & $x$ & & & & & $x$ & & $x$ & $x$ & \\
\hline Prune & & $x$ & & & & & $x$ & $x$ & $x$ & $x$ \\
\hline
\end{tabular}

This can be shown likewise as:

- pips or kernel

- visual aspect

- taste

- $\quad$ smell - only if bad

- shape

- colour

- varieties

- season

The model is applied rigorously to the fruit seed type, pip or kernel, the varieties and the season. Generally, the descriptions include detailed information as to varieties, their season and gustative value. This is clearly a concern for Furetière and accepted by Basnage as the majority of fruit descriptions are copied from one dictionary to the other with only minimal changes. This brings us back as to who wrote which entries and senses: Furetière, Basnage or a third party, Dr Régis. To go further on this, it is worthwhile looking at two fruits from southern climes: olives and oranges.

\subsection{Exotic fruits: olives and oranges}

The entries for olive trees, 'olivier', differ totally. According to Furetière the tree is:

OLIVIER. s. m. Grande arbre qui porte pour fruit des olives. L'Olivier jette des feuilles longues qui se termine en pointe, \& vont en diminuant. Elles sont verdes par dessus, blanchastres par dessous, grosses \& grasses, \& d'un goust amer $\&$ brusque. Il porte en Juin des fleurs blanches et grappuës en forme de raisins, d'où vient un fruit qui est d'abord verd, puis pasle, \& estant meur plainement noir. On le cuillle en Novembre ou Decembre. On le laisse sur terre jusqu'à ce qu'il se ride; puis on le met sous la meule ou le pressoir pour en tirer de l'huile. Les anciens faisoient cas de dix sortes d'olives. Son bois est beau, veineux $\&$ madré, $\&$ brusle aussi bien vert que sec. Il y a des oliviers sauvage qu'on appelle autrement Ethiopiques, qui font plus petits que les domestiques, qui sont espineux, \& qui produisent force olives plus savoureuses que les autres, encore qu'elles soient moins grosses. Ils jettent tous deux une gomme rousseaastre \& mordante qui ressemble à la scamonée, qui est mise au rang des poisons, \& qui a pourtant beaucoup d'usages en Medecine. olea sylvestris folio duro subtus incano, differe du precedent en ce qu'il est plus petit en toutes ses parties. L'Olivier \& le chêne ont une telle inimitié, que si on les plante l'un auprès de l'autre, ils se font mourir. Matthiole. En Latin oleaster, olea 
sylvestres, olea sativa. La lie d'huile ou des olives cuites \& pressurées s'appelle amurcia en Medecine \& en Chymie.

Whereas the entry for the DU 1701 reads:

OLIVIER. s. m. Arbre dont il y a deux especes, un cultivé \& l'autre sauvage. L'olivier cultive est de moienne grandeur ; son tronc est noüeux ; son écorce lisse, de couleur cendrée ; son bois solide, jaunâtre, d'un goût un peu amer. Ses feullles sont oblongues, étroites, presque semblables à celles du saule, pointuës, charnuës, grasses, de couleur verte obscure en dessus, blanchatre en dessous. Il pousse dans le mois de Juin des fleurs blanches, disposées en grape : chaque fleur est d'une seule piece évasée en haut, \& fenduë en quatre parties ; mais retrecie par le bas en tuyau. Quand cette fleur est passée, il lui succede un fruit mou, ordinairement oblong, charnu, plein de suc, qu'on appelle olive. Ce fruit est d'abord verd, puis pâle, \& enfin noir, lorsqu'il est entierement meur : il est plus ou moins gros suivant les lieux où il naît : il renferme dans sa chair un noyau rempli d'une semence oblongue. En Latin olea sativa. L'olivier sauvage qu'on appelle olea sylvestris folio duro subtus incano, differe du precedent en ce qu'il est plus petit en toutes ses parties. Les feuilles de l'olivier sont astringentes. Son bois est beau, veineux \& madré. Les Sculpteurs, les Statuaires l'emploient pour faire divers ouvrages. On dit que l'olivier \& le chêne ont une telle inimitié, que si on les plante l'un auprès de l'autre, ils se font mourir.

Some small parts of the text are common to both editions, but otherwise someone has taken the time to completely rewrite the text, and it is difficult to see why. The reference to oaks and olives not being compatible is given a reference by Furetière, but in 1701 only receives a "on dit que" (it is said that).

The entry for olive fruit is more straightforward:

OLIVE. s. f. Fruit à noyau dont on tire beaucoup d'huile, \& dont on fait des salades. Les olives de Luques sont vertes, douces \& menuës. Celles d'Espagne sont grosses, charnuës $\&$ ameres. On vend les olives à la chopine, à la pinte, au baril. L'huile d'olive ne vaut rien à peindre, parce qu'elle ne seche point. Pour tirer cette huile, après avoir ramassé les olives on les laisse quelque temps sur le pavé afin qu'elles s'égoutent, \& qu'elles meurissent davantage ; ensuite on les reduit en pate par le moien d'une meule de moulin ; on met cette pâte dans des grands cabas, \& on verse de l'eau bouillante dessus ; enfin on presse le tout, \& on separe facilement l'huile qui nage sur l'eau. Les olives ont un goût fort amer \& fort desagreable au sortir de l'arbre. Afin de les rendre bonnes à manger, on les fait tremper dans de l'eau, ou bien dans une lessive faite avec des cendres de chêne, de vigne ou autre semblable, $\&$ de la chaux, jusqu'à ce qu'elles aient perdu toute leur amertume ; après on les met dans des vaisseaux de terre ou de verre, \& on les couvre d'une eau mediocrement salée, y ajoutant du fenouil, ou de l'écorce de citron ou d'orange, ou quelque autre aromat. Les merles, les grives, les étourneaux sont fort friands des olives.

The entries for the tree differ totally between the two editions, for the fruit the situation is clearer as Furetière only gives a very brief definition, which is reused in 1701, but a lengthy discussion on the extraction of oil and the preservation of the fruit is added. Insofar as Basnage is unlikely to have had first-hand experience of olive production, it seems quite likely that another hand is at work. If we turn to 'orange', a similar situation arises.

The tree is described in 1690 as: 
ORENGER. Subst. masc. C'est un arbre qui est vert toute l'année. Ses feuilles sont $\underline{\text { larges, }}$ grosses, lissées, odorantes $\&$ pointues par le bout, $\&$ ressemblent à celles du laurier. Ses branches sont souples \& minces. Son escorce est verde \& blanchastre. Sa fleur est blanche \& de bonne odeur, dont on fait de l'eau parfumée qu'on appelle de fleur d'orenge. Il porte du fruit toute l'année. Quelques Naturalistes le confondent avec les limons \& les pommes d'Adam, quoi que ceux-cy portent des feuilles plus grandes, \& la fleur sembable au citronnier, $\&$ le fruit deux ou trois fois plus gris, dont la peau est pasle et inegale, à cause des petites fentes $\&$ incisions qui ressemblent à des morsures; ce qui leur a fait donner le nom de pommes d'Adam.

This follows pretty much the pattern for fruit trees of the northern climes, but there is no mention of pips or the varieties. The 1701 entry reads:

ORENGER. subst. masc. C'est un arbre qui a ses branches souples \& minces, \& son écorce verte \&blanchâtre. Ses feuilles sont épaisses, larges, lisses, pointues par le bout, semblables à celles du laurier, mais plus grandes, toujours vertes, soutenuës par une petite feuille échancrée en cœur. Ses fleurs sont blanches, de bonne odeur, composées de cinq feuilles disposées en rond. Il porte du fruit toute l'année, qu'on nomme orenge. Voyez Orenge. Cet arbre s'appelle en Latin aurantium, ou malus aurantia. On fait de l'eau de la fleur d'orenge, qu'on appelle eau naphe, qui est bonne dans les fievres malignes $\&$ pour fortifier le cœur; on en donne aussi aux femmes qui sont en travail d'enfant.

Small amounts of information are reused, but this is mostly a total rewrite with the addition of 'eau d'orenge' as a treatment for fevers and also as being good for the heart.

Turning to the fruit, the two editions vary greatly so that the 1690 reads:

ORENGE. Subst. fem. Fruit round de couleur d'un jaune foncé, plein de jus acide propre pour faire des sauces. L'orenge est presque semblable aux limons, \& a les mêmes proprietez des citrons. Sa graine est semblable, mais son jus est plus acide, $\&$ son escorce plus espaisses $\&$ plus amère. Il y en a d'aigres, \& de douces qu'on appelle bigarrades; \& d'autres de moyen goult qu'oin appelle vineuses, \& d'autres pissenlit. Les Espagnols disent que c'est une grande veillaquerie de manger les perdrix sans orenge. Ce mot vient du Latin corrompu aurantia, comme prouve Menage après Saumaise; d'autres de malum arum. Les Arabes disent narangium.

In the 1701 edition the text has been restructured to read:

ORENGE ou plutôt ORANGE, ainsi que l'écrit l'Academie. Subst. fem. Fruit rond de couleur jaune, odorant, qui croît à un arbre appellé orenger. Il est couvert d'une écorce peu épaisse, \& divisé en plusieurs loges remplies d'une substance vesiculeuse, \& pleine de suc, dans laquelle se trouvent quelques semences. En Latin aurantium, ou malum aureum. Les Anciens ont donné aux orenges le nom de mala aurea, à cause de leur couleur jaune ou dorée ; ils devoient plutôt les appeller aurata. De la vient que dans la basse Latinité on a dit aurantia au lieu d'aurata, comme prouve Menage après Saumaise. De ce mot aurantia est venu celui d'orenge. Les Arabes disent narangion. Il y a des orenges aigres, \& de douces; il y en a de la Chine, de Portugal, de grosses, de petites. Les Espagnols disent que c'est une veillaquerie de manger les perdrix sans orenge.

This is both a rewrite and a reorganization. Furetière shows his interest in food by underlining the use of orange in sauces. His text seems a bit disorganised and the comparisons with lemons make it difficult to follow. The 1701 text seems clearer and more scientific in form and is clearly written by someone with an interest in botany. It is also interesting to see 
recognition of the spelling used by the Académie française, it is just strange that the writer then does not adopt that spelling.

\section{Conclusion}

Obviously, in the context of LandLex, orchards and orchard trees play an important role in the landscape. A full LandLex enquiry, as done for 'Bellis perennis' and 'hill' will cover all of Europe and several centuries. This means looking at a variety of fruit trees as conditions change across the varied climatic conditions found in Europe, fruits as oranges and lemons are exotic in the north, but are an essential part of the landscape, along with vines, in warmer areas. In this text however, we have decided to explore only a limited numbers of trees and their fruit in a single dictionary, the Dictionnaire Universel of Antoine Furetière in its first and revised editions.

This text has dealt with two main issues: orchard trees in the seventeenth century landscape with fruit and tree descriptions in the 1690 and 1701 editions of the Dictionnaire Universel and the question of authorship of the entries.

What is clear is that Furetière attacked his description of fruit and trees with method, and this was carried over in most cases into the 1701 edition. Descriptions of trees would include the fruit they carry, height and varieties as well as details of the leaves and fruit. For many fruits, the most important section of the entry concerns the varieties of fruit, their gustative qualities and season. This reflects the great importance of fruit at the end of a meal in seventeenth century academic circles where the most succulent fruits were keenly sought (Michel 2002). With changes in cooking, sauces were also becoming more refined and fruit played an important part, notably fruits as oranges, as witnessed in the writings of La Varenne (La Varenne 1651). As we have seen Furetière had a keen interest in food. The other factor is the changes in gardening practice and hence the importance of works as that of de la Quintinie (La Quintinie, de 1690). Thus, both Furetière and Basnage were showing the tastes and interests of their time. The presence of a third hand in the 1701 edition brings in more information on medical practice and on botany.

A clear picture is emerging on fruit and fruit trees, and that is we have three writers at work. Furetière likes to produce lengthy lists of varieties of fruit for their gustative qualities, Basnage as a landowner with his own orchards is happy to copy over these lists and just add in his knowledge on more up-to-date gardening techniques, whilst a third writer is concerned to rewrite any entry, or part of entry, that concerns medical or botanical issues. Basnage and Dr Régis are important sources of data as they are keen to cite authors and works, but it is Dr Régis who takes the time to rewrite whole entries and introduce current work on the scientific fields that concern him. As many of the texts are available in digital libraries, this means that we can start to compile the ideal library of a working lexicographer and his scientific specialist. For the moment, the data points to the hand of Dr Régis. With fully digitised versions of both editions it will be possible to carry out authorship analysis to confirm this and to see what other entries were from the hand of Dr Régis. Similarly, it will be possible to see where Basnage himself chose to differ from Furetière, in all probability in matters of law and religion.

Much remains to be done, but as digital versions become available in the coming months it will become easier to look at all trees mentioned in the DU and also to look closely at the terms of gardening and gardeners, as well as of botany and the natural sciences. Data in the 
DU provides an important window on the late seventeenth century world. However, it is also more than a window as it will be the starting point for studies into the role of dictionaries in the dissemination of scientific knowledge from the seventeenth century onwards.

\section{Bibliography}

Monographs

Considine, John (2014): Academy Dictionaries 1600 - 1800. Cambridge: Cambridge University Press.

Galleron, Ioana (2020) : Molière dans le Dictionnaire universel. In: French Studies. Graveleau, Sara (2018) : "Les hérésies sont d'utiles ennemies". Itinéraire d'Henri Basnage de Beauval (1656-1710), avocat de la République des Lettres et penseur de la tolérance civile. Angers: Université d'Angers.

Khemakhem, Mohamed, Luca Foppiano, et Laurent Romary. (2017): “Automatic Extraction of TEI Structures in Digitized Lexical Resources using Conditional Random Fields" In: electronic lexicography, eLex 2017, Sep 2017, Leiden, Netherlands. https://hal.archivesouvertes.fr/hal-01508868v1.

La Quintinie, de, Jean. (1690): Instruction pour les jardins fruitiers et potagers. [Volume 1] /, avec un Traité des orangers, suivy de Quelques réflexions sur l'agriculture, par feu M. de La Quintinye,... Tome I. [-II.]. Paris: Claude Barbin.

La Varenne, Pierre François (1651): Le cuisinier françois, enseignant la manière de bien apprester et assaisonner toutes sortes de viandes... légumes,... [...]. Paris: Pierre David. Michel, Dominique (2002): "Le dessert au XVIIe siècle". In: Dix-septième siècle 217 (4): 655-62. https://doi.org/10.3917/dss.024.0655.

Quémada, Bernard. (1967) : Les Dictionnaires du Français Moderne 1539 - 1863. Paris: Didier.

Rey, Alain (2006) : Antoine Furetière : Un précurseur des Lumières sous Louis XIV. Paris: Fayard.

Villalva, Alina, Williams, Geoffrey (2019) (eds): The Landscape of Lexicography. LisboaAveiro, Portugal: Centro de Linguística da Universidade de Lisboa-Universidade de Aveiro. Williams, Geoffrey (2020). Architecture in the 1701 Dictionnaire Universel: Encoding and analysing architectural terminology with digital humanities methodologies. In: The Language of Art and Culture Heritage: a Plurilingual and Digital Perspective, édité par Zotti, Valeria, Pano Alaman A. (forthcoming 2020). Newcastle: Cambridge Scholars Publishing. 190-209. Williams, Geoffrey. (1998): Collocational Networks : Interlocking Patterns of Lexis in a Corpus of Plant Biology Research Articles. In: International Journal of Corpus Linguistics 3 (1): 151-71.

Williams, Geoffrey (2019): The problem of interlanguage diachronic and synchronic markup. In: The Landscape of Lexicography. Villalva, Alina., Williams, Geoffrey (eds). 81-98.

\section{Dictionaries}

Académie Française (1694): Le dictionnaire de l'Académie françoise, dédié au Roy. T. 2. L-Z. 1ère. Paris: Vve J. B. Coignard et J. B. Coignard. http://catalogue.bnf.fr/ark:/12148/cb35153876f.

Accademia della Crusca (1612): Vocabolario degli Accademici della Crusca. Venezia: Giovanni Alberti. http://www.accademiadellacrusca.it/en/digital-shelves/crusca-online. Chambers, Ephraim (1728): Cyclopaedia, or, An Universal Dictionary of Arts and Sciences. 2 vol. London: J. and J. Knapton. or, An Universal Dictionary of Arts and Sciences. 
Corneille, Thomas (1694) : Le dictionnaire des arts et des sciences. Tome 1 / par M. D. C... Paris: Vve J. B. Coignard. http://gallica.bnf.fr/ark:/12148/bpt6k50507s.

Diderot, Denis., Le Rond d'Alembert, Jean (1751): Encyclopédie ou Dictionnaire raisonné des sciences, des arts et des métiers. 17 vol. Paris. http://encyclopedie.uchicago.edu.

Furetière, Antoine (1690): Dictionnaire Universel, contenant généralement tous les mots françois tant vieux que modernes et les termes des sciences et des arts. La Haye et Rotterdam. http://gallica.bnf.fr/ark:/12148/bpt6k50614b.

Furetière, Antoine. (1701): Dictionnaire universel, contenant généralement tous les mots françois tant vieux que modernes, \& les termes des sciences et des arts. Tome $1 /$,... par feu messire Antoine Furetière,... 2e édition revue, corrigée et augmentée par M. Basnage de Bauval. La Haye et Rotterdam: Arnoud et Reinier Leers.

http://gallica.bnf.fr/ark:/12148/bpt6k5841680f.

Furetière, Antoine. (1701): Dictionnaire universel, contenant généralement tous les mots françois tant vieux que modernes, \& les termes des sciences et des arts. Tome $2 /, \ldots$ par feu messire Antoine Furetière,... 2e édition revue, corrigée et augmentée par M. Basnage de Bauval. Vol. Tome 3 O-Z. 3 vol. La Haye et Rotterdam: Arnoud et Reinier Leers. Johnson, Samuel. 1785. Dictionary of the English Language, Vol 2. $6^{\mathrm{e}}$ éd. Vol. 2. London. www.archive.org/details/dictionaryofeng02johnuoft.

Nicot, Jean, de Ranconnet, Aimar (1606) : Thresor de la langue francoyse tant ancienne que moderne : auquel... sont les mots propres de marine, vénerie et faulconnerie.... Avec une) Grammaire francoyse et latine et le recueil des vieux proverbes de la France. Ensemble le Nomenclator ([Reprod.]) / ramassez par Aimar de Ranconnet,... ; revu et augmenté... par Jean Nicot,... [Jean Masset] ; de Junius... Paris: David Doucet. http://catalogue.bnf.fr/ark:/12148/cb34696509r.

Richelet, Pierre (1680): Dictionnaire françois : contenant les mots et les choses, plusieurs nouvelles remarques sur la langue françoise, ses expressions propres, figurées et burlesques, la prononciation des mots les plus difficiles, le genre des noms, le régime des verbes... Geneva: J.-H. Widerhold.

\section{Acknowledgements}

The Author is grateful to the support received from the Consortium Cahier, part of the national HumaNum infrastructure that allocated seed money enabling work to begin on the digitalisation of the 1701 Dictionnaire universel. The BasNum project is a four year French nationally funded BasNum programme (ANR-18-CE38-0003-01 ). 